\title{
OFFICE BUILDING ADAPTATION AND THE GROWING SIGNIFICANCE OF ENVIRONMENTAL ATTRIBUTES
}

\section{Introduction}

Dense cities are crucial to human-kinds attempts to mitigate the effects of global warming and to mitigate calamitous levels of climate change, as the environmental footprint of those in dense cities is lower than those in rural areas and low density cities (Batty, 2006. Brand, 2009). The overwhelming proportion of building stock will be around for many decades; for example $87 \%$ of the building stock the UK will have in 2050 is already built (Kelly, 2008). Furthermore the design, construction and operation of most existing stock predates current considerations of sustainability, and with new building adding between $1-2 \%$ to the total building stock annually (Knott, 2007), it is in the adaptation of existing buildings that sustainability in the built environment may be delivered. The question is; are voluntary or mandatory measures more likely to bring about the necessary changes?

Recognising the importance of office adaptation as a means of reducing total building related greenhouse gas emissions, the City of Melbourne initiated the voluntary 1200 Buildings Program in 2008. The City of Melbourne strategy to become a carbon neutral city by 2020 has three key strands (City of Melbourne, 2003);

i. leading edge design of buildings to deliver a reduction of $50 \%$ of the greenhouse gas emissions (or 1,850,000 tonnes) from City of Melbourne buildings,

ii. implement new and renewable energy use greening the power supply, and;

iii. sequestration of the residual emissions to deliver zero net emissions or offsetting.

Reported emissions in 2002 were 3.75 million tonnes of carbon dioxide equivalent $\left(\mathrm{t} \mathrm{CO}_{2}-\mathrm{e}\right)$ and commercial buildings were said to account for $59 \%$ of that total (2.21 million t $\mathrm{CO}_{2}$-e). Commercial sector emissions are estimated to be 9.9 t $\mathrm{CO}_{2}$-e per employee by 2020 and a reduction to 4.1 t $\mathrm{CO}_{2}$-e is the target. This figure translates into an emission reduction target of $1004 \mathrm{kt} \mathrm{CO}_{2}$-e on 2020 business as usual emissions. For existing office buildings, a retrofit program of $66 \%$ of total stock or 1200 buildings was established. The 1200 Buildings Program is now halfway through the timeframe to 2020 . This research shows whether there has been a shift in the market towards environmental adaptation by assessing the importance of environmental attributes within office building adaptations.

Reliance on legislation is slow and sustainability is a recent driver, particularly in Australia. It was only in 2006 that environmental sustainability for offices was introduced into the Building Code of Australia in the form of energy efficiency. It will take many decades to transform the stock to comply with current code standards. Another recent change was the Mandatory Disclosure Act 2010 which requires an energy rating of all commercial space exceeding 2000 square metres at the point of sale or lease renewal (Warren and Huston, 2011). These minimum standards for energy efficiency applied to new build and adaptation projects over a certain threshold of work. It is possible the Mandatory Disclosure legislation will have a 
faster impact as the current typical lease term in Australia is 5 years (Warren and Huston, 2011). Given that the first major piece of office building sustainability related legislation was established in 2006; how important are environmental attributes within office building adaptations? This research addresses two questions; (a) are environmental attributes important in the adaptation of office buildings? And; if so (b), how has the level of importance changed over time? The overall aim is to analyse the importance of attributes in office building adaptations at the city scale and at two points in time to determine whether the situation in Australia is changing.

\section{Attributes in Building Adaptation}

The definition adopted is; "any work to a building over and above maintenance to change its capacity, function or performance' in other words, 'any intervention to adjust, reuse, or upgrade a building to suit new conditions or requirements" (Douglas, 2006). This wide-ranging definition enables an analysis of adaptations from minor to major works, across and within use. Across use adaptations are excluded from this research. Furthermore 'adaptation' refers to changes to buildings and not to the measures used to respond to consequences of climate change. Decision making with regards to building adaptation is multifaceted (Wilkinson et al, 2014). Bullen (2007), Bullen and Love (2011), Remøy and Van Der Voordt (2007) and Langston et al (2008) all found that the precise classification of the attributes influencing adaptation whether, it was within use or across use was not only subjective, but complex and challenging.

Attributes effecting adaptation are economic, environmental, social, technological, legal and physical (Wilkinson, 2011. Wilkinson et al, 2014). Physical attributes determine whether adaptation is possible and/or desirable with all studies identifying age as important (Ball 2002, Nutt et al. 1976). Some construction forms and materials make adaptation more expensive and/or difficult because of regulatory compliance requirements (Bullen 2007). Gann and Barlow (1996) found height, construction type, and frame condition important. A London study discovered floor size was significant and buildings with unusual floor plates or size were harder to adapt compared to open plan space (Kincaid, 2002). Services core location was important because it affected flexibility and ability to sub-divide space (Arge 2005, Szarejko and Trocka-Leszczynska 2007). A central location gave greater scope for sub-dividing the floor plate and minimised loss of net lettable area. Detached buildings were easier and more desirable for adaptation and contractors worked faster with less user disruption (Isaacs in Baird et al. 1996). Access or, the number of entry and exit points to buildings impacted on the ease of adaptation (Remøy \& van der Voordt 2006). With building width Arge (2005) and Povall and Eley (in Markus 1979) identified optimal benchmarks as 15 to 17 metres, demonstrating these buildings suited more space configurations and user needs. Likewise the technical grid, or distance between structural columns, influenced the ease of adaptation for new uses (Arge 2005). Floor strength was vital in Kincaid's (2002) London study, a 3 to 5 $\mathrm{kN} / \mathrm{m}^{2}$ floor suited retail, office and hospital uses. Floor strength determined possible land uses; where it was not viable to adapt to office use when floor was $3 \mathrm{kN} / \mathrm{m}^{2}$, unless strengthening or replacement was undertaken. 
The technical grid and services equipment was important to evaluate whether the building could accommodate extra capacity (Arge 2005). Raised floors permitted IT cabling to be upgraded easily and zone based internet communication technology provision allowed greater flexibility and adaptability; a sought after attribute (Arge 2005). Modularity described modules which could be rearranged, replaced, combined, or interchanged (Arge 2005). Buildings with potential for lateral or vertical extension were more adaptable as size could be increased to suit new uses and occupiers (Arge 2005). Elasticity, the potential for sub-division for either letting or sale, allowed owner's to keep up with changes in demand (Arge 2005).

Physical location was important in terms of proximity to public transport which is environmentally positive as it reduces private car emissions. The amount of on-site parking was significant where little or no public transport was available (Douglas, 2006). Land use attributes were important (Arge, 2005) as existing land use impacted the scope for new or changed uses. Though existing planning zones define legally permissible development, sites can be rezoned and a proactive policy approach in Toronto increased adaptation (Heath 2001).

Swallow (1997) concluded adaptation was affected by tenure since it influenced the amount a party was willing to invest. Owners have an interest in perpetuity, whereas lessees have a short term interest for the lease term; typically five years in Melbourne. Owners can be institutional or private. Institutional owners invest to maximise the return on investment and appoint consultants to evaluate adaptation potential. Private owners, may or may not use consultants and may be located offshore with less knowledge of local market conditions. This group may hold property for various reasons, such as future development potential, for rental income or capital growth. Private owners may engage in less adaptation, however this is unknown.

The ability to adapt is affected by occupation. With single tenants, when the lease expires owners can adapt, however, with multiple tenants, leases are unlikely to terminate simultaneously and the building may be partly empty (and not income earning) before owner's can adapt. Owners can terminate leases early, compensating or decanting tenants temporarily or permanently.

Historic listing protects architecturally or socially important buildings for societal benefit (Ball 2002). Heritage adaptation includes possible additional costs of using traditional materials, techniques and craftspeople (Bullen 2007). With legal issues, adaptation benefitted from proactive policies and legislation (Gann \& Barlow 1996, Ball 2002). Urban regeneration studies in London and Bristol docklands found proactive policy and legislation enhanced retention of existing stock (Bromley et al. 2005).

Negative factors included proximity to motorway and air traffic noise making properties less desirable, as does the existence of deleterious materials such as asbestos. Negative factors produce force up costs (Remøy, 2006). Binder's (2003) study into re-use of dilapidated buildings found some carried a social stigma making change of use adaptation problematic, for example there was a negative association with prisons. 
Adaptation has to be economically viable, though costs can be traded against social and environmental gains (Kincaid 2002); a perspective of triple bottom line accounting theory. Based on whether the intention is to occupy or let, different features are more or less important. Arge (2005) found owner occupied stock had higher 'adaptability' criteria compared to speculative designs, and although they were more expensive they provided a greater return on investment over the whole lifecycle. However there has to be demand for economically viable adaptation; Ball (2002) found positive user demand and active marketing by stakeholders were vital in the reuse of vacant stock in Stoke-on-Trent where the demand was for low cost accommodation for start-up businesses.

Market research is critical as it reveals economic aspects such as yield, post adaptation value and investment. Chau et al (2003) found a positive relationship between adaptation and the value of refurbished residential blocks in Hong Kong. Lower vacancy rates were a positive economic indicator in adapted buildings (Ball, 2002). Depending on condition, it is possible to increase quality, rental and capital values with adaptation (Highfield 2000). Quality is measured by amenity features, services, fixtures and fittings. Australian offices are graded by the Property Council of Australia as Premium (the best), A, B, C and $\mathrm{D}$ grade. Total costs are important and owners can deliver a project at around $66 \%$ of new build, however where buildings are complex adaptation costs can surpass new construction (Davis Langdon 2008).

Environmental aspects have increased the scope and extent of adaptation (Kincaid 2002). There can be overlap with social, economic and location aspects, for example proximity to public transport provides environmental, location, economic and social benefits; thus some attributes can be interpreted on multiple levels. The most important environmental impact is the greenhouse gas emissions associated with operational energy use (Douglas 2006). Buildings assessed under assessment methods, such as Green Star in Australia, meet standards in respect of environmental criteria including energy use. Water economy, an important environmental attribute within Australia, is included in Green Star (ABGC, 2010). Most stock was built with little attention to minimising water use and adaptation offers an opportunity to reduce; recycle, harvest and re-use water to increase sustainability.

The transport occupants use affect building sustainability (Kincaid 2002). Public transport has lower per capita emissions than individuals driving cars, and proximity to public transport features in environmental assessments (Davis Langdon 2008). However, car-parking is a desirable attribute in the Property Council of Australia building quality matrix and is a contradiction in terms of market perceptions of quality and the perception of environmental features as being highly desirable. Finally energy efficiency, an important environmental attribute, was mandated in the Building Code of Australia in 2006 and an earlier study found that environmental attributes were not important in adaptations from 1998 to 2008 (Wilkinson and Reed, 2011). 


\section{Research method and design}

This research used a building adaptation database to ascertain which attributes are most important (Wilkinson \& Reed, 2011. Wilkinson in Wilkinson et al, 2014). This approach has the advantages that it is not reliant on the subjective views of individuals and secondly, that large numbers of adaptations can be evaluated. Other studies adopted a case study approach using small samples of buildings (Blakstad 2001, Ball 2002, Kincaid 2002, Kucik 2004, Arge 2005, Remøy and van der Voordt 2007, Remøy and Wilkinson 2012). Using the attributes found important in these studies, the researcher designed and assembled a building adaptation database, however the approach is profoundly different due to the detailed quantity of data and the method used. Adaptation attributes formed the fields for the database. The sources used to populate the database comprised the Building Commission of Victoria Building Permit database, 'Cityscope' database (RPData 2008) and the Department of Sustainability and Environment database 'PRISM' (DSE 2008). Commercial data was obtained from the Property Council of Australia (PCA 2007, PCA 2008) with visual inspections completing the database. Much research is limited by sample size however every adaptation recorded in the Building Permit database between January 2009 and 31st July 2011 was analysed; in total 1,422 events. The database included variables which were coded as physical, social, legal, economic and environmental. The study examined building adaptations in a mature commercial market in the Melbourne Central Business District (CBD) in the Hoddle grid, a distinct geographical location that has been continuously occupied since 1834. Melbourne is a global city with a population of 4.14 million people and this makes the findings relevant to other global cities (ABS, 2012).

\section{Principal Component Analysis.}

Principle Component Analysis is a reliable, verified technique of weighting dimensions in cross sectional data (Joliffe, 2002) with the capacity to reveal, untangle and sum up configurations of connection within a data set (Heikkila 1992). From a number of original variables Principle Component Analysis condenses data into a smaller set of new merged factors with a least workable loss of information (Jackson 2003). Here Principle Component Analysis reduced the dimensionality of attribute data relating to adaptation. The aim was to ascertain the highest level of variance explained by an interpretable group of factors and all attributes were appraised. Initially all variables were input into the Principle Component Analysis to generate a lesser number of components where factors with Eigenvalues exceeding 1.0 were retained. The factors were rotated using an oblique 'Oblimin' rotation method; the result being a table of specific factors which includes the loadings of single building attributes.

Different types of adaptation were contained in the database and this paper analyses 'alterations' which comprised $89 \%$, or 1272 , of all adaptations. Adaptations were classified according to extent of works undertaken, 'alterations' constituted the second level of adaptation after minor works for example, typical works would comprise the fit out of one or more floors within an office building but not the whole 
building. To determine meaning the researcher interprets the pattern of the factor loadings; a subjective process (Hair et al. 1995). Following an analysis of the loadings across the factors the minimum threshold was 0.5 as recommended by Tabachnick \& Fidell (2001). With the list of each factor containing high loading building attribute variables, the researcher assigned factor names. For the retained property attributes the Kaiser-Meyer-Olkin (KMO) score and a Bartlett test of sphericity are shown in table 1.

Table 1 Kaiser-Meyer-Olkin and Bartlett's Test

\begin{tabular}{lll}
\hline Kaiser-Meyer-Olkin Measure of Sampling Adequacy. & .606 \\
Bartlett's Test of Sphericity & Approx. Chi-Square & 1621.785 \\
& Df & 45 \\
& Sig. & .000 \\
\hline
\end{tabular}

The Principle Component Analysis was continued as the KMO of 0.606 exceeded 0.50 and with the significance less than 0.05. Kaiser-Meyer-Olkin (KMO) is measure of sampling adequacy and the Bartlett's test of sphericity were used to determine whether Principle Component Analysis was suitable for data studied. According to results of these criteria, the data was found to be most appropriate for applying Principle Component Analysis (Eyduran et al, 2009 Dunteman, 1989). For a highly detailed description of the research methodology, design of the database and statistical method please see Wilkinson (2011).

\section{Results}

Ten property attributes were analysed and produced a four component table (table 2). After the initial extraction using 42 variables, the reduced variables retained for 'alterations' adaptation events were vertical services location, number of storeys, Property Council of Australia grade, NABERS, type of construction, Green Star rating, parking, historic listing, street frontage (metres) and aesthetics. The first heading under initial Eigenvalues shows the variance explained by each of the ten variables (Dunteman, 1989). Four components explained $70 \%$ of the original variance. The third section shows the Eigenvalue of each of the four rotated components. Note that as the components are correlated with each other there is some overlap in the variance explained by each factor (Jackson 2003). The total amount of variance explained by the four components cannot be obtained by adding the four Eigenvalues. For the rotated solution the component loadings and correlations are given in the table 3 . Table 2 shows the four components for this Principle Component Analysis. 
Table 2. Total variance explained Principle Component Analysis 'alterations' adaptation events

\begin{tabular}{|c|c|c|c|c|c|c|c|}
\hline \multirow[t]{2}{*}{ Component } & \multicolumn{3}{|c|}{ Initial Eigenvalues } & \multicolumn{2}{|c|}{$\begin{array}{l}\text { Extraction } \\
\text { Sums of } \\
\text { Squared } \\
\text { Loadings }\end{array}$} & \multirow{2}{*}{$\begin{array}{l}\text { Extraction } \\
\text { Sums of } \\
\text { Squared } \\
\text { Loadings } \\
\\
\begin{array}{l}\text { Cumulative } \\
\%\end{array}\end{array}$} & \multirow{2}{*}{$\begin{array}{l}\text { Rotation } \\
\text { Sums of } \\
\text { Squared } \\
\text { Loadingsa } \\
\\
\text { Total }\end{array}$} \\
\hline & Total & $\begin{array}{l}\% \text { of } \\
\text { Variance }\end{array}$ & $\begin{array}{l}\text { Cumulative } \\
\%\end{array}$ & Total & $\begin{array}{l}\% \text { of } \\
\text { Variance }\end{array}$ & & \\
\hline 1 & 3 & 32 & 32 & 3 & 32 & 32 & 3 \\
\hline 2 & 1 & 15 & 46 & 1 & 15 & 46 & 1 \\
\hline 3 & 1 & 14 & 60 & 1 & 14 & 60 & 2 \\
\hline 4 & 1 & 10 & 70 & 1 & 10 & 70 & 1 \\
\hline 5 & 1 & 9 & 79 & & & & \\
\hline 6 & 1 & 8 & 87 & & & & \\
\hline 7 & 1 & 5 & 92 & & & & \\
\hline 8 & 0 & 4 & 96 & & & & \\
\hline 9 & 0 & 2 & 99 & & & & \\
\hline 10 & 0 & 1 & 100 & & & & \\
\hline \multicolumn{8}{|c|}{ Extraction Method: Principal Component Analysis. } \\
\hline \multicolumn{8}{|c|}{$\begin{array}{l}\text { a When components are correlated, sums of squared loadings cannot be added to obtain a } \\
\text { total variance. }\end{array}$} \\
\hline
\end{tabular}

Table 3. Pattern Matrix a for 'alterations' adaptation events

\begin{tabular}{|c|c|c|c|c|}
\hline Property Attributes & $\begin{array}{l}\text { Environmental / } \\
\text { physical } \\
\text { (Component 1) }\end{array}$ & $\begin{array}{l}\text { Social / physical } \\
\text { (Component 2) }\end{array}$ & $\begin{array}{l}\text { Physical } \\
\text { (Component 3) }\end{array}$ & $\begin{array}{l}\text { Environmental } \\
\text { (Component 4) }\end{array}$ \\
\hline $\begin{array}{l}\text { Property Council of } \\
\text { Australia grade }\end{array}$ & 0.89 & -0.06 & -0.02 & -0.20 \\
\hline NABERS & 0.82 & 0.33 & 0.18 & 0.16 \\
\hline Aesthetics & 0.78 & -0.28 & 0.03 & 0.01 \\
\hline Number of Storeys & -0.63 & 0.10 & 0.46 & 0.07 \\
\hline Historic listing & 0.20 & -0.76 & -0.24 & -0.12 \\
\hline Construction type & 0.00 & 0.52 & -0.13 & -0.22 \\
\hline Parking & -0.31 & -0.51 & 0.37 & -0.25 \\
\hline Street frontage (metres) & 0.10 & 0.20 & 0.96 & -0.04 \\
\hline Vertical services location & -0.01 & -0.21 & 0.62 & 0.03 \\
\hline Green Star rating & -0.06 & -0.07 & -0.05 & 0.95 \\
\hline
\end{tabular}

Extraction Method: Principal Component Analysis.

Rotation Method: Oblimin with Kaiser Normalization.

a. Rotation converged in 9 iterations. 
Table 4 summarises the main Principle Component Analysis component categories and the component names ascribed by the interpretation, which is a subjective task and is largely derived from the labels given to attributes by previous researchers noted above and in Wilkinson (2011).

Table 4. Summary of Principle Component Analysis factors 'alterations' adaptations 2009 to 2011

\begin{tabular}{|l|l|l|}
\hline $\begin{array}{l}\text { Component } \\
\text { number }\end{array}$ & $\begin{array}{l}\text { Component } \\
\text { name }\end{array}$ & Component attributes \\
\hline 1 & $\begin{array}{l}\text { Environmental } \\
\text { and physical } \\
(32 \%)\end{array}$ & $\begin{array}{l}\text { Property Council of Australia quality grade (29\%) } \\
\text { NABERS rating (26\%) } \\
\text { Aesthetics (25\%) } \\
\text { Number of storeys (20\%) }\end{array}$ \\
\hline 2 & $\begin{array}{l}\text { Social and } \\
\text { physical (15\%) }\end{array}$ & $\begin{array}{l}\text { Historic listing (42\%) } \\
\text { Construction type (29\%) } \\
\text { Parking (28\%) }\end{array}$ \\
\hline 3 & Physical (14\%) & $\begin{array}{l}\text { Street frontage (60\%) } \\
\text { Vertical services location (40\%) }\end{array}$ \\
\hline 4 & $\begin{array}{l}\text { Environmental Star rating (100\%) } \\
(10 \%)\end{array}$ & Green \\
\hline
\end{tabular}

The attributes Property Council of Australia building quality grade, NABERS rating, aesthetics and number of stories were all highly or very highly loaded on component 1 (table 4). These variables explain $32 \%$ of the original variance with component one comprising four attributes. The first three relate to environmental and social sustainability, whilst the fourth relates to building size with regards to height which is a physical attribute. Offices with a high Property Council of Australia building quality grade are likely to have high energy and environmental ratings (NABERS, 2012) and in this case, can be interpreted as an environmental attribute. NABERS, is an energy rating measure clearly is an environmental attribute. Aesthetics is loaded on component one and relates to building appearance indicating that buildings having a poor appearance, such as a worn or outdated form or look are less likely to be adapted. Attribute four, 'number of stories' is strongly and negatively loaded and is a physical characteristic. These attributes are labelled 'environmental and physical'.

In component two, three attributes loaded highly; historic listing, construction type and parking (table 4) and described $15 \%$ of variance. Component two attributes were influenced by social and physical factors. Historic listing is has social characteristics or value, whereas parking and the type of construction is construed as physical attributes. Historic listing limits, to some degree, the level of work which owners or users can undertake. Parking was negatively loaded which implies that provision of parking does not positively impact on adaptation in the way it did previously as an amenity. The public transportation argument with lower per capita emissions appears to be having a positive impact in Melbourne. Finally, the type of construction form, being either skeleton frame or load bearing, has bearing on the flexibility and ease and the cost of building alterations. 
Two attributes, street frontage (building width) and vertical services location are very strongly and moderately loaded on component three and explained $14 \%$ of the variance (table 4$)$. The attributes are described as physical and related to building size and dimensions as well as the level of flexibility in terms of space configuration. One attribute Green Star rated very strongly loaded on component four and described $10 \%$ of variance (table 4). The attribute measures an environmental rating for a floor or a whole building and thus the variable is labelled environmental.

It is acknowledged that other researchers have categorised some of these attributes differently in the past; for example parking can be referred to as a functional attribute or heritage listing can be referred to as a political or a legal attribute. This part of the Principle Component Analysis is subjective and the researcher is challenged to create a label which best encapsulates the collection of attributes within the component.

'Alterations' are the second level of adaptation works and represented the highest number of events, demonstrating that most owners engaged in this type of adaptation from January 2009 to July 2011. This is a change from earlier activity (Wilkinson and Reed, 2011), but still indicates reasonably high market confidence. The period covered by the study immediately followed the Global Financial Crisis of 2008, whilst 1422 events occurred, about 46 events per month, it is work that was not as extensive as that undertaken during the period 1998 to 2008 (Wilkinson and Reed, 2011). The earlier study was able to use all computerised building permit data from 1998 to 2008 however this study found no evidence that environmental attributes were important (Wilkinson \& Reed, 2011) and this second follow up study was undertaken a reasonable time after, and also after environmental regulation was enforced in the Building Regulations in 2006 and in the Mandatory Disclosure Act in 2010. 'Alterations' adaptations are typically undertaken when leases expire and new tenants move in or to refresh spaces to attract new tenants in order to maintain the low vacancy rates.

\section{Discussion and interpretation}

When all building permits were considered, works to office buildings represented $55 \%$ of all CBD activity, followed by retail at 29\% and it is apparent the City of Melbourne strategy is focussed on the sector which is most active with the potential to deliver the highest level of emissions reductions. The 1272 'alterations' adaptation events were analysed in the Principle Component Analysis, because according to Jackson (2003), at least 100 cases or five times the number of attributes are required to undertake a reliable Principle Component Analysis. As there were 42 attributes to analyse the minimum sample size would be 210 and 'alterations' adaptations only met this criteria (table 5). 
Table 5 Total events Melbourne CBD 2009 to 2011

\begin{tabular}{|c|c|}
\hline Adaptation level & Total events January 2009 to July 2011 \\
\hline Level 1 - Minor works & 1 \\
\hline Level 2 - Alterations & 1272 \\
\hline Level 3 - Change of use & 3 \\
\hline Level 4 - Alterations \& extensions & 123 \\
\hline Level 5 - New build & 17 \\
\hline Level 6 - Demolition & 6 \\
\hline
\end{tabular}

The results of the alterations Principle Component Analysis clearly showed that ten attributes group into a four components and accounted for $70 \%$ of variance in adaptation. This is a reasonable degree of importance for a small number of attributes and the 32 attributes which were progressively removed account for the $31 \%$ of importance in adaptation.

The results of the alterations Principle Component Analysis clearly shows that two environmental attributes, the rating tools NABERS and Green Star are important in building adaptation at a minor level and this is a major change from the earlier study covering the period 1998 to 2008 (Wilkinson, 2011). As with the previous study, property attributes do not group together in a neat pattern, for example physical attributes pair with environmental and social attributes in one component. The earlier Principle Component Analysis based study concluded that it was possible that previous studies, which looked at decision making in building adaptation using a smaller number of case study projects, had simplified the groupings of attributes based on logic rather than a quantitative process. The Principle Component Analysis overcomes this, using a quantitative objective methodology and a large sample to determine which attributes account for the most variance in adaptation and how they group together.

Physical attributes featured in three of the four components and show that the physical attributes remained important, however other attributes such as social and environmental are included. Whilst economic attributes did not feature greatly it is possible to interpret the Property Council of Australia building quality grade as an economic attribute as well as an environmental one. Similarly the provision of parking and an historic listing could enhance a building's capital and rental values.

\section{Comparison to $1998-2008$ study}

Wilkinson's (2011) analysis of 5290 'alterations' adaptations from 1998 to 2008 did not find environmental attributes to be important. The KMO of 0.612 is similar to the Principle Component Analysis for the 2009 to 2011 period; however the total amount of variance explained is higher at $82 \%$ compared to 70\% (tables 4 and 6). Both Principle Component Analyses produced four component solutions, though more attributes were included in the 1998-2008 Principle Component Analysis. In the earlier study 13 attributes were important; six of those, or 46\%, featured in the second Principle Component Analysis and these were Property Council of Australia quality grade, aesthetics, number of 
stories, historic listing, street frontage and vertical services location. Although the results reveal a certain level of consistency between the two Principle Component Analyses, it also shows that there is some volatility in the results that should be treated with some caution. Given that this is a quantitative technique there is no opportunity to ask individuals why some attributes feature in one Principle Component Analysis and not another. It could be posited that the absence of the attributes typical floor area and gross floor area in the second Principle Component Analysis are captured within the Property Council of Australia attribute whereby buildings with higher grades typically have larger floor plates and gross floor areas. The four 'new' attributes in the second Principle Component Analysis were; NABERS rating, construction type, parking and Green Star rating. The important attributes from the first study were labelled physical and size, amenity and flexibility potential, land and social and did not include any environmental attributes (Wilkinson \& Reed, 2011). Table 6 shows the 13 attributes in the Principle Component Analysis from the 1998 to 2008 study.

Table 6 Summary of Principle Component Analysis factors 'alterations' adaptations 1998 to 2008

\begin{tabular}{|c|c|c|}
\hline $\begin{array}{l}\text { Component } \\
\text { number }\end{array}$ & $\begin{array}{l}\text { Component name } \\
\text { (\% of variance } \\
\text { explained) }\end{array}$ & $\begin{array}{c}\text { Component attributes } \\
\text { (\% of variance explained within factor) }\end{array}$ \\
\hline 1 & Physical and size $(42 \%)$ & $\begin{array}{l}\text { Degree of attachment to other buildings (22\%) } \\
\text { Typical floor area }(22 \%) \\
\text { Gross floor area }(19 \%) \\
\text { Number of storeys }(19 \%) \\
\text { Site access }(18 \%)\end{array}$ \\
\hline 2 & $\begin{array}{l}\text { Amenity and flexibility } \\
\text { potential }(20 \%)\end{array}$ & $\begin{array}{l}\text { Existing land use ( } 40 \%) \\
\text { Vertical services location (35\%) } \\
\text { Property Council of Australia building grade (24\%) }\end{array}$ \\
\hline 3 & Land $(11 \%)$ & $\begin{array}{l}\text { Street frontage }(60 \%) \\
\text { Property location }(40 \%)\end{array}$ \\
\hline 4 & Social $(9 \%)$ & $\begin{array}{l}\text { Historic listing }(45 \%) \\
\text { Age in } 2010(28 \%) \\
\text { Aesthetics }(27 \%)\end{array}$ \\
\hline
\end{tabular}

\section{Conclusions}

The research questions were; are environmental attributes important in the adaptation of office buildings, and if so, how has the level of importance changed over time? On the basis of this analysis, environmental attributes were important in alterations adaptations in the Melbourne CBD between January 2009 and July 2011. The NABERS energy rating tool, required by the Mandatory Disclosure legislation of 2010 (Warren and Huston, 2011), accounted for $26 \%$ of the importance within component one which explained $32 \%$ of the original variance. In the fourth component the environment attribute Green Star, the voluntary environmental assessment tool, accounted for $100 \%$ of importance within the component which explained $10 \%$ of the original variance. It is argued that the degree of importance is relatively limited, to $8 \%$ and $10 \%$ respectively, for NABERS and Green Star. However this is a change from the earlier study. 
The second question asked how the level of importance of environmental attributes has changed over time. This analysis shows it has become important compared to the results of the 1998 to 2008 study (Wilkinson, 2011). Two pieces of legislation appear to have affected the market. Firstly, the 2006 energy efficiency requirement of the Building Code of Australia is now making an impact in the market. Secondly, the introduction of Mandatory Disclosure legislation in 2010 and the short term nature of Melbourne commercial leases means a significant number of properties are assessed annually; this legislation appears to be having an effect where a greater number of buildings are now rated. In contrast the 37 property owners who had formally entered the 1200 Building Program in 2009 to 2010 (City of Melbourne 2012) would not have affected the 1272 adaptation events analysed in this study. It is likely that the Mandatory Disclosure legislation effect will continue as more leases expire over the coming three year period and the opportunities for adaptations involving some aspects of sustainability present themselves to building owners. This research also shows that the Green Star attribute, which is a voluntary measure typically adopted by owners of the highest quality stock was of lesser importance here and the voluntary approach may not have as much impact as a mandatory approach in this market. This study concludes that the alterations adaptation market in office buildings in Melbourne has changed in terms of the importance of environmental attributes and this is possibly due to the positive influence of the Mandatory Disclosure legislation; as such, it augers well for the future.

\section{References}

Arge, K. (2005). "Adaptable office buildings: theory and practice." Facilities 23(3): 119-127. Arup, (2008). Existing Buildings. Survival Strategies. Melbourne.

ABS (Australian Bureau of Statistics) 2012.

http://www.abs.gov.au/ausstats/abs@.nsf/Products/3218.0 2010-

11 Main+Features Victoria?OpenDocument\#PARALINK5 Accessed 7th April 2012.

Australian Green Building Council (AGBC), 2010. Australian Green Building Council. website accessed 13 th June 2010

Baird, G., Gray, J., Isaacs, N., Kernohan, D., McIndoe, G. (1996), Building Evaluation Techniques, McGraw-Hill, 1996

Ball, R. M. (2002). Re use potential and vacant industrial premises: revisiting the regeneration issue in Stoke on Trent. Journal of Property Research. 19: 93-110.

Batty, S., (2007). Paradoxes of Sustainable Development. Property Management. Vol. 24, No. 3, pp. 207-218. Binder, M. (2003). Adaptive Reuse and Sustainable Design: A Holistic Approach for Abandoned Industrial Buildings. The School of Architecture and Interior Design. Cincinnati, Cincinnati. Master of Architecture.

Blakstad, S. H. (2001). A Strategic Approach to Adaptability in Office Buildings. Faculty of Architecture, Planning \& Fine Arts, Norwegian University of Science \& Technology. Doktor Inegnior 282.

Brand, S., 2009. Whole Earth Discipline. Atlantic Books, London.

Bromley R.D.F., A. R. Tallon, \& Thomas, C. J. (2005). "City centre regeneration through residential development: Contributing to sustainability." Urban Studies 42(13): 2407-2429.

Bullen, P. A. (2007). Adaptive reuse and sustainability of offices. Facilities. 25: 20-31.

Bullen, P. A., and Love, P.E. (2011). A New Future for the Past: A Model for Adaptive Reuse Decisionmaking. Built Environment Project and Asset Management. 1: ISSN 2044 124X. Chandler, I. 1991. Repair and Refurbishment of Modern Building. B. T. Batsford Ltd, London. Chau, K. W., Leung, A. Y. T., Yui, C. Y., and Wong, S. K. (2003). "Estimating the value enhancement effects of refurbishment." Facilities 21(1): 13-19. 
City of Melbourne (2003). Zero Net Emissions by 2020. A Roadmap to a Carbon Neutral City. City of Melbourne. Melbourne

City of Melbourne, (2005). City Plan 2010. Towards a Thriving and Sustainable City. Melbourne, City of Melbourne: 100 .

City of Melbourne iCompass. 2009. www.melbourne.vic.gov.au accessed July to November 2009. City of Melbourne (2012),

http://www.melbourne.vic.gov.au/AboutCouncil/PlansandPublications/AnnualReport/2010/Performa nce/OurGoals/Goal5/highlights/Pages/1200BuildingsProgram.aspx accessed 24th September 2012.

City Scope Online, (2010), 447 Collins Street, RP Data - CityScope, accessed 18/03/2010 from

www.cityscopeonline.com.au/DataView.aspx

Davis Langdon (2008). Opportunities for existing buildings. Deep emission cuts. innovative thinking 8.

Department of the Environment, Water, Heritage \& Arts (2008). Mandatory Disclosure of Office Energy Efficiency: 100 .

Department of Environment, Climate Change and Water. 2010 www.nabers.com.au accessed September 2010.

Douglas, J. (2006). Building Adaptation Butterworth Heinemann.

Department of Sustainability and Environment (DSE) (2008). PRISM, State Government of Victoria.

Dunteman, George H. (1989). Principal components analysis. Thousand Oaks, CA: Sage Publications, Quantitative Applications in the Social Sciences Series, No. 69.

Eyduran, E., K. Karakus, S. Karakus and F. Cengiz, 2009. Usage of factor scores for determining relationships among body weight and some body measurements. Bulg. J. Agric. Sci., 15: 373-377

Gann, D. M. and J. Barlow (1996). "Flexibility in building use: the technical feasibility of converting redundant offices into flats." Construction Management \& Economics 14(1): 55-66.

Hair, J.F, Anderson, R.E, Tatham, R.L, and Black, W.C. (1995), Multivariate Data Analysis, 4th edition, Englewood Cliff, NJ: Prentice Hill

Heikkila, E.J. (1992) 'Describing Urban Structure', Review of Urban and Regional Development Studies, 4, pp 84-101.

Highfield, D. (2000), Refurbishment and upgrading of buildings. London, E \& FN Spon.

Horvath, R.J. (1994) 'National development paths 1965 - 1987: measuring a metaphor', Environment \& Planning A, 26, pp 285-305.

Jackson, J.E. (2003) A Users Guide to Principal Component Analysis. John Wiley \& Sons Inc. ISBN 0471 471348

Joliffe, I.T. (2002) 2nd ed. Principal Component Analysis. Springer.

Kelly, M.J. 2008. Britains Building Stock. A Carbon Challenge. http://www.lcmp.eng.cam.ac.uk/wpcontent/uploads/081012_kelly.pdf

Kincaid, D. (2002). Adapting buildings for changing uses: guidelines for change of use refurbishment. London, Spon Press.

Knott., J. (2007). Green Refurbishments. Where to next? RICS Oceania e-News Sustainable: 5-7.

Kucik, L., M. (2004). Restoring Life: The Adaptive Reuse of a Sanatorium. School of Architecture and Interior Design. Cincinnati, University of Cincinnati. Masters of Architecture: 93.

Langston, C., Francis K. W. Wong, Eddie C.M. Hui, Li-Yin Shen (2008). "Strategic assessment of building adaptive reuse opportunities in Hong Kong." Building \& Environment. 43 (10), 1709-1718: ISSN 0360-1323.

Markus, A.M. (ed) (1979) Building Conversion and Rehabilitation: Designing for Change in Building Use, NewnesButterworth, London.

NABERS (2012). http://www.nabers.gov.au/public Accessed 11th November 2012.

Nutt, B., Walker, B, Holliday, S., and Sears, D. 1976. Obsolescence in housing; theory and applications. Saxon House, Farnborough.

Property Council of Australia (2007). Benchmarks Survey of Operating Costs. Melbourne Office Buildings. Property Council of Australia. Australia: 36.

Property Council of Australia (2008). July 2008 The Office Market Report. The Office Market Report. PCA, Property Council of Australia.

Property Council of Australia. (2008). existing buildings / survival strategies. A toolbox for re-energising tired assets. Property Council of Australia: 67.

Remøy, H. T. and van der Voordt, T.J.M., (2006). A new life: Transformation of vacant office buildings into housing. CIBW70 Trondheim International Symposium June 12-14 2006, Trondheim, Norway, 2006. 
Norwegian University of Science and Technology, NTNU. ISBN 82-771-031-7.

Remøy, H. T. and T. J. M. van der Voordt (2007). "A new life: conversion of vacant office buildings into housing." Facilities 25(3/4): 88-103.

Remøy, H. T. \& Wilkinson, S. J. 2012. Office building conversion and sustainable adaptation: A comparative study. Journal of Property Management. ISSN.0263-7472. Issue 3 Volume 30.

R P Data (2008). Melbourne Cityscope, Cityscope Publications Pty Ltd.

Swallow, P. (1997). "Managing unoccupied buildings and sites " Structural Survey 15(2): 74-79.

Szarejko, W. and E. Trocka-Leszczynska (2007). "Aspect of functionality in modernization of office buildings." Facilities 25(3): 163-170.

Tabachnick, B.G. \& Fidell, L.S., (2001). Using Multivariate Statistics, Fourth Edition. Needham Heights, MA:

Allyn \& Bacon. ISBN 0-321-05677-9.

Warren, C. M. J. and Huston, S. (2011). Promoting energy efficiency in public sector commercial buildings in Australia. Proceedings of RICS Construction and Property Conference. COBRA: Construction and Building Research Conference, Salford, United Kingdom, (128-134). 12-13 September 2011.

Wilkinson, S.J. (2011) The Relationship between Building Adaptation and Property Attributes. PhD thesis Deakin University. http://dro.deakin.edu.au/view/DU:30036710 accessed 24th September 2012.

Wilkinson, S. J., \& Reed, R., 2011. Examining and quantifying the drivers behind alterations and extensions to commercial buildings in a central business district. Construction Management \& Economics 29:7, 725-735 ISSN: 01446193.

Wilkinson, S.J., Remøy, H. T. \& Langston, C. 2014. Sustainable Building Adaptation: Innovations in Decision-making. Wiley-Blackwell. ISBN: 978-1-118-47710-6 